Przemysław Wechta

Adam Mickiewicz University of Poznań

Faculty of Social Sciences

Institute of Sociology

e-mail:wechta@amu.edu.pl

\title{
Koncepcja bezinteresowności ekonomicznej Talcotta Parsonsa
}

\section{Talcott Parsons' concept of economic disinterestedness}

The task of the paper is to analyze Talcott Parsons' concept of economic disinterestedness, which the classical American sociologist introduced at an early stage of his work. It is aimed at economic orthodoxy, whose permanent foundation is the still vital figure of homo oeconomicus. The concept of disinterestedness is about crossing the limits of one's own advantage in economic activities. When justifying the concept, Parsons refers to Alfred Marshall and his concept of a "gentleman of the world of free industry and entrepreneurship" and Max Weber's concept of the "spirit of capitalism". According to Parsons, the embodiment of disinterestedness in advanced capitalism should become a specific type of bureaucracy.

Keywords: disinterestedness, ethics, bureaucracy

JEL Classification: A14

\section{Wprowadzenie}

„Kto dziś czyta Spencera?”. Tym pytaniem Talcott Parsons otwiera swoje dzieło The Structure of Social Action (1968, s. 3). Dla amerykańskiego socjologa Herbert Spencer jest reprezentantem skrajnego indywidualizmu w myśleniu o społeczeństwie. Parsons, ogłaszając śmierć idei angielskiego filozofa i socjologa, odrzuca wiarę $\mathrm{w}$ istnienie samoregulującego się mechanizmu gospodarczego, w którym 
dążenie do własnej korzyści służy najlepszemu zaspokojeniu potrzeb wszystkich. Dla autora wydanego po raz pierwszy w roku 1937 dzieła, świadka wielkiego kryzysu i wysiłków w jego przezwyciężaniu w postaci polityki New Deal, opieranie systemu gospodarczego na tym rzekomo samoregulującym się mechanizmie jest ograniczeniem, a nie podstawą rozwoju gospodarczego.

Obecnie przekonanie to nie jest jednak powszechnie akceptowane. Pogłoski o śmierci homo oeconomicus, który stał się symbolem dążenia do własnej korzyści w działaniach gospodarczych, są mocno przesadzone. Wprawdzie jego krytyka jest trwałym elementem dyskusji na temat kapitalizmu, przybierając na sile w okresach kryzysu gospodarczego, lecz pojawia się on w coraz nowszych odsłonach w teoriach naukowych (Dzionek-Kozłowska, 2018). Homo oeconomicus jest przedstawiany jako

aksjomat, aprioryczna prawda, oczywiste samo przez się twierdzenie, użyteczna fikcja, typ idealny, konstrukcja heurystyczna, niepodważalny fakt znany z codziennego doświadczenia, a także typowy dla stosunków kapitalistycznych wzorzec zachowania. (Blaug, 1995, s. 127).

W artykule przedmiotem analizy są prace Parsonsa, napisane przed powstaniem takich dzieł, jak The Social System (1951) czy Economy and Society (1956). Analogicznie jak czyni się to w stosunku do Karola Marksa, można tutaj mówić o osiągnięciach „młodego” Parsonsa, w celu wyodrębnienia w jego twórczości okresu poprzedzającego największe dokonania, jak teoria systemu społecznego, instytucji, zgeneralizowanych środków wymiany. Nie musi to oznaczać, że jest to etap mniej istotny. Właściwe młodości idealizm, optymizm poznawczy i ontologiczny razem $\mathrm{z}$ pewną dozą niedojrzałości mogą i w tym przypadku stać się atutem, ponieważ pozwalają (ponownie) odkryć zasoby motywacyjne i etyczne gospodarowania w kapitalizmie.

„Młody” Parsons konsekwentnie skupia się w swoich pracach na analizie przekraczania granic własnej korzyści w działaniach gospodarczych. Bezinteresowność ekonomiczna odnosi się do tych jednostek, które w instytucjonalnej strukturze gospodarki kapitalistycznej zdołają je przekroczyć. A nie muszą to być wcale przypadki rzadkie i niezwykłe. Co więcej, stanowią one ważny zasób rozwoju społeczeństwa kapitalistycznego, na ogół niedostrzegany lub ignorowany przez ortodoksję ekonomiczną.

\section{Ortodoksja ekonomiczna i jej wrogowie}

Według Talcotta Parsonsa ortodoksja myślenia ekonomicznego stanowi pewien główny i trwały trend obecny w ekonomii klasycznej czy szkołach marginalistycznych. Charakterystyczne jest dla niej założenie, że własna korzyść (self-interest) jednostki stanowi ostateczny cel podejmowanego przez nią działania gospodarczego. W dążeniu do realizowania własnych korzyści amerykański socjolog dostrzega jednak - co stanowi sedno jego krytyki - ograniczenie ludzkiej aktywno- 
ści. Własna korzyść staje się granicą dla działań ekonomicznych. Możliwość przekraczania narzucanych tym dążeniem ograniczeń wyznacza przedmiot analizy zawartej w koncepcji określanej mianem bezinteresowności. Odpowiedź na pytanie o cel działań ekonomicznych rozdziela ortodoksję ekonomiczną od stanowiska Parsonsa.

Parsons wyróżnia korzeń, z którego wyrasta ortodoksyjny sposób podejścia do zjawisk ekonomicznych. To utylitaryzm. W teorii ekonomicznej zaowocował on spopularyzowaniem pojęcia użyteczności. Amerykański socjolog przyjmuje, że podstawowa zasada typu idealnego ortodoksyjnej teorii ekonomii głosi, iż nauka ekonomiczna koncentruje się przede wszystkim na procesach, poprzez które żyjące w społeczeństwie jednostki zabezpieczają środki zaspokojenia indywidualnych potrzeb. Własna korzyść jednostki oznacza dążenie do maksymalizacji ich zaspokojenia, wyznaczając tym samym ostateczny cel działań gospodarczych, określany mianem maksymalizacji użyteczności.

Według Parsonsa w ortodoksyjnej teorii ekonomicznej bierze się pod uwagę trzy podstawowe typy warunków, w których jednostki powiązane społecznie maksymalizują użyteczność. Pierwszy to konkurencja. Każda z jednostek pracuje na rzecz zaspokojenia swoich potrzeb przy danym układzie czynników rynkowych i produkcyjnych, którego jednak nie jest w stanie zmienić w sposób zamierzony. Drugi to monopol, w którym istnieje możliwość ich zmiany. Natomiast trzeci to kolektywizm (collectivism). W tym przypadku społeczeństwo jest w sposób zamierzony organizowane i centralnie kontrolowane w celu zdobycia środków zaspokojenia potrzeb (Parsons, 1991a, s. 184). Wymiana i jej zasadniczy środek, czyli pieniądz przekształcają maksymalizację zaspokojenia potrzeb w maksymalizację dochodu pieniężnego. Dzięki temu ekonomia, jak twierdzi Parsons, jako jedyna nauka społeczna automatycznie uzyskuje możliwość ilościowej analizy przedmiotu swoich badań (1991a, s. 184).

Kolejnym czynnikiem, który modyfikuje sposoby osiągania korzyści własnych przez jednostki żyjące w społeczeństwie, jest podział własności. Ortodoksyjna teoria ekonomii uwzględnia, że cel wspólnoty, jakim jest produkcja dóbr i usług przez jednostki, jest traktowany jako środek. Kwestią kluczową staje się powiązanie procesu zarobkowania jako bezpośredniego celu jednostki z procesem produkcyjnym jako celem wspólnoty. Według Parsonsa rozwiązaniem wysuwanym przez ortodoksyjną teorię ekonomii jest podporządkowanie maksymalizacji zaspokojenia potrzeb istniejącemu w danym społeczeństwie podziałowi własności. Pociąga on za sobą określony podział dochodów wynikający z zastosowania czynników produkcji przez ich właścicieli czy dysponentów (1991a, s. 184).

Ponadto czynnikiem modyfikującym maksymalizację zaspokojenia potrzeb przez jednostki, który uwzględnia ortodoksja ekonomiczna, jest podział pracy. Jeżeli założyć, że podstawą działań gospodarczych jest konkurencyjny indywidualizm, to wówczas każdy przypadek kooperacji dla wspólnego celu stanowi element monopolu. Ale, jak zauważa Parsons, w teorii ekonomii uczyniono wyjątek, uznając rodzinę, a nie indywiduum, za jednostkę procesu konsumpcji (1991a, s. 185).

Konkurencyjny indywidualizm został porzucony przez teorię ekonomiczną na rzecz jednostki produkcyjnej, którą stanowi złożona organizacja współpracują- 
cych indywiduów. Nowoczesna korporacja stała się antytezą samotnego Indianina polującego na jelenia, który dla Johna Locke’a był punktem wyjścia badań (Parsons, 1991a, s. 185).

Własna korzyść jako maksymalizacja zaspokojenia indywidualnych potrzeb uległa zmodyfikowaniu, przyjmując formę maksymalizacji dochodu pieniężnego w warunkach podziału własności i pracy.

Z pojęciem własnej korzyści wiąże się zagadnienie motywacji aktywności gospodarczej. Według Parsonsa teoria ekonomiczna w przeważającej części rozwinęła się w ramach myśli utylitarnej, co zaowocowało tym, że w trwały sposób została ona związana z ideą głoszącą, iż ludzka motywacja ma głównie charakter egoistyczny. Zasada racjonalnego dążenia do własnej korzyści była tak szeroko stosowana, że egoizm stał się istotą podejścia ekonomistów do ludzkiego działania. Tendencja ta uległa wzmocnieniu pod wpływem psychologicznego hedonizmu. Jednolitość zachowań zostaje w nim sprowadzona do ludzkiej skłonności do dążenia do przyjemności. Wpisuje ona w działanie jednostki obojętność na dobro innych. Egoizm zostaje ściśle powiązany z postulatem racjonalności działań (Parsons, 1968, s. 161-162).

Według Parsonsa podejście ortodoksyjne redukuje społeczeństwo do jednostek i grup o określonych potrzebach (1991a, s. 183). Trwałym fundamentem działań gospodarczych czyni użyteczność i egoizm. Uznanie, że jedynie one nimi kierują, prowadzi do wyrugowania $\mathrm{z}$ analizy ekonomistów ortodoksyjnych aktywnych, twórczych elementów w procesie gospodarowania. Ortodoksja ekonomiczna neguje założenie, że jednostki czy grupy mogą integrować się wokół wspólnie podzielanych celów ostatecznych. Prowadzi to do atomizmu w postrzeganiu życia społecznego, sprowadzając go do chaosu, jaki panuje między walczącymi z sobą jednostkami (Camic, 1991, s. LVII). Można wprawdzie wyobrazić sobie społeczeństwo składające się z mnogości jednostek powiązanych i traktujących siebie nawzajem jedynie jako środek lub przeszkodę dla własnych celów, ale jego istnienie - jak twierdzi Parsons - nie jest empirycznie możliwe. Brakuje w nim bowiem czynnika, który będzie spajał życie społeczne. Parsons (1991b, s. 156-158) odrzuca założenie o „mechanicznym” uzgadnianiu celów indywidualnych zgodnie z koncepcją oświeconej korzyści własnej (enlightened self-interest) obecną na przykład w filozofii Johna Locke'a i Adama Smitha. Skłania ona każdą jednostkę do postrzegania własnej korzyści jako powiązanej z korzyścią całego systemu, niewywołującej w nim żadnej szkody. Parsons przeciwstawia się tej tezie, którą przypisuje teoriom czystego indywidualizmu. Utrzymują one, że wzajemne świadczenia między jednostkami są w całości produktem ubocznym ich oświeconej korzyści własnej, która polega na tym, że potrzeby i pragnienia innych są środkiem do osiągania własnych celów. Według Parsonsa społeczeństwo oparte jedynie na powiązaniu interesów jednostek nigdy nie istniało. Co więcej, społeczeństwo zależy zawsze w większym lub mniejszym stopniu od bezinteresownego wykonywania świadczeń i utrzymywania w tym celu szczególnych sankcji etycznych (1991c, s. 47).

W twórczości Parsonsa odnaleźć można radykalne wypowiedzi, gdy stwierdza wręcz, że każda konkretna motywacja działań wymaga elementów, których 
nie można adekwatnie rozpatrywać w ramach teorii ekonomicznej. Analiza ekonomiczna poprzestaje na badaniu motywacji jedynie jako środka, nie biorąc pod uwagę ostatecznych celów działania, na przykład ich egoistycznego czy altruistycznego charakteru (1991d, s. 275).

Swoimi sprzymierzeńcami w walce $\mathrm{z}$ ortodoksją ekonomiczną Parsons czyni między innymi Alfreda Marshalla i Maksa Webera. Jak twierdzi amerykański socjolog, Marshall zdecydowanie wyszedł poza utylitarno-hedonistyczną tendencję, właściwą dla tradycyjnej myśli ekonomicznej, uwypuklania egoizmu w gospodarczych działaniach jednostki (Parsons, 1968, s. 163).

Dzieło Principles of Economics Marshalla otwiera następująca definicja:

\begin{abstract}
Ekonomia polityczna lub ekonomika jest studium rodzaju ludzkiego w jego codziennych sprawach życiowych; bada ona tę część działań indywidualnych i społecznych, która jest najściślej związana ze zdobywaniem i użytkowaniem materialnych rekwizytów dobrobytu. (Marshall, 1947/1920, s. 1, tłum. za Dzionek-Kozłowska, 2007, s. 33)
\end{abstract}

Parsons podkreśla znaczenie dalszego wywodu Marshalla, w którym uznaje on, że ekonomia jest „z jednej strony badaniem bogactwa”, z drugiej ,znacznie ważniejszej strony jest częścią studiów nad człowiekiem”. Oprócz idei religijnych, ludzki charakter w największym stopniu kształtują codzienna praca i zasoby materialne. Parsons wyprowadza $\mathrm{z}$ powyższych wywodów wniosek, że studia nad mechanizmem zaspokojenia potrzeb, które stanowią podstawowy przedmiot ekonomii marginalistycznej, tworzą jedynie część, i to mniej istotną, ekonomii Marshalla (Parsons, 1968, s. 134-135; Dzionek-Kozłowska, 2007, s. 33).

Za zasadniczą cechę Weberowskiego ducha kapitalizmu Parsons uznaje z kolei brak jakichkolwiek związków z hedonizmem i utylitaryzmem. Z punktu widzenia stanowiska hedonistycznego duch kapitalizmu jest wręcz całkowicie irracjonalny (Parsons, 1991e, s. 28). Dla Webera natomiast irracjonalnym popędem jest nieograniczona żądza zysku. Popęd do zarobku, do zdobycia pieniędzy, do możliwie wysokiego zysku finansowego nie ma jako taki nic wspólnego z kapitalizmem. Nieograniczona żądza zarobku nie jest w najmniejszym stopniu równoznaczna z kapitalizmem ani też z jego „duchem”. Przeciwnie, kapitalizm może oznaczać jej poskromienie, a przynajmniej racjonalne ograniczenie (Weber, 1995, s. 73-74).

Koncepcja bezinteresowności nie służy jednak wyrugowaniu z analizy działań gospodarczych dążenia do własnej korzyści. Swoim zakresem obejmuje natomiast możliwość przekraczania granic interesów prywatnych przez działające jednostki. W podejściu Parsonsa przejawia się wieloznaczność pojęcia ortodoksji. $\mathrm{Z}$ jednej strony dobrze oddaje ono specyfikę głównego nurtu ekonomii w stosunku do innych nauk społecznych. Jest stosowane na oznaczenie poglądów uważanych za słuszne, które nie mogą być przedmiotem uzupełnienia czy wzbogacenia. W tym znaczeniu można mówić o ortodoksji ekonomicznej czy ortodoksji marksistowskiej. Termin ten posiada jednak szlachetniejszy, pierwotniejszy sens. Dla Greków oznaczał on opinię prawdziwą, słuszną, właściwą (Kozyr-Kowalski, 1990, s. 197-213). Korzyść własna jest prawdziwym motywem działalności go- 
spodarczej. Parsons nie odrzuca tego założenia, w swojej analizie skupia się natomiast na poszukiwaniu dowodów, że nie jest ona motywem jedynym. Odnajduje je między innymi w teoriach Alfreda Marshalla i Maksa Webera. W koncepcjach rycerskości gospodarczej czy ducha kapitalizmu autorzy ci wykraczają poza perspektywę utylitarną i hedonistyczną w ujmowaniu działań gospodarczych.

\section{Dżentelmeni i purytanie}

Przeciwko ortodoksji ekonomicznej Parsons kieruje swoją koncepcję bezinteresowności (disinterestedness). Amerykański socjolog konsekwentnie stosuje ją w całej swojej twórczości. Do czego prowadzi bezinteresowność w działaniach gospodarczych? Najogólniej rzecz ujmując, do przekraczania granic własnej korzyści przez podejmujące je jednostki. Proces ten w ujęciu Parsonsa dotyczy wielu wymiarów działania gospodarczego. Można go analizować ze względu na:

(1) cel działania gospodarczego;

(2) motywację działania gospodarczego;

(3) racjonalność działania gospodarczego.

Bohaterem, który zdołał przezwyciężyć naturę homo oeconomicus, jest opisywany przez Alfreda Marshalla dżentelmen świata wolnego przemysłu i przedsiębiorczości, kierujący się w działaniach rycerskością gospodarczą. Cechuje go „bezinteresowne poświęcenie działalności produkcyjnej dla niej samej, bez innych ukrytych motywów". Jego działalność nie może być rozpatrywana jedynie jako środek dla osiągania prywatnych celów (Parsons, 1968, s. 163).

Bezinteresowność to cecha przypisywana przez Parsonsa również działaniom gospodarczym podejmowanym przez purytanów, których role w kształtowaniu osobliwej dla kultury Zachodu etyki gospodarczej, określanej mianem ducha kapitalizmu, analizuje Max Weber. Ich celem jest zdobycie zysku, lecz nie po to, aby czerpać przyjemność z jego wydawania. Według Parsonsa duch kapitalizmu jest przeciwieństwem dążenia do własnej korzyści rozumianej jako środek osobistej satysfakcji. Zarabianie staje się etycznym obowiązkiem (1991f, s. 62).

Jaki jest cel działań gospodarczych? Homo oeconomicus dąży do zaspokojenia potrzeb, ale cele działań gospodarczych mogą być znacznie szersze. Istnieją zresztą różne typy potrzeb, które pociągają za sobą różne skutki w życiu gospodarczym. Mogą być to „potrzeby, które wywołują działania”. Alfred Marshall zalicza do nich potrzeby biologiczne. Kierują one człowiekiem na niższych stadiach rozwoju. Jak zauważa Parsons, już na współczesnym mu etapie rozwoju gospodarczego potrzeby biologiczne mają niewielki wpływ na efektywny popyt na przykład na ubrania czy domy. Dla wyjaśnienia ludzkich działań są one niewystarczające. Znacznie istotniejsze dla rozwoju ludzkości są „,potrzeby dostosowane do działań". To one stanowią właściwy cel gospodarczych działań dżentelmena. Zapewniają standard życia, którego oznakami są wzrost ludzkiej inteligencji, energii oraz szacunku do samego siebie. W teorii Marshalla kwestia zaspokojenia potrzeb wykracza poza ujęcie utylitarne, staje się natomiast zagadnieniem etycz- 
nym. Potrzeby mogą być również „sztuczne” i „prostackie”. Składają się one wówczas na komfort życia. Dla Marshalla ich przykładem są „,rozwiązłe kaprysy mody". Traktuje je jako zachcianki, którym brakuje trwałego zakorzenienia w życiu (Parsons, 1968, s. 139-141).

Cele działań gospodarczych nie muszą jednak kończyć się na zaspokojeniu potrzeb. Poza użyteczność wykracza formowanie szlachetnych cech ludzkiego charakteru. Wiara Marshalla w wartości absolutne i przyczynowy związek cech charakteru z działaniami, które je rozwijają i wyrażają, spowodowała, że jego ekonomia stała się nie tylko badaniem bogactwa, ale również studium nad człowiekiem. Parsons uznaje tego typu podejście za przeciwwagę dla ekonomii utylitarnej. Sprowadzenie całego porządku gospodarczego do mechanizmu zaspokojenia potrzeb oznacza, że działania, jak i ludzkie cechy, które się w nich przejawiają, nie są celem, ale jedynie środkiem. W ujęciu Marshalla rozwój charakteru jako cel ludzkiego życia kieruje działaniami gospodarczymi (Parsons, 1968, s. 135-138). Ostatecznie umożliwiają one człowiekowi gospodarującemu osiągnięcie ideału dżentelmena. Jego szlachetność w porównaniu z homo oeconomicus polega na wykazywaniu energii, inicjatywy, przedsiębiorczości z jednej strony, z drugiej zaś na racjonalności, oszczędności, pracowitości, honorze w interesach. Ponadto dba on o „szlachetną fabrykę życia społecznego”, jaką stanowi rodzina.

Jednak nie każdy rodzaj posunięć gospodarczych prowadzi do formowania cech szlachetnych. Dostosowanie działań jedynie do danych potrzeb prowadzi do lenistwa, marnotrawnej stagnacji, niewolniczego podporządkowania zwyczajowi, braku ambicji. Z kolei dążenie do zaspokojenia potrzeb sztucznych kształtuje takie cechy, jak zbytkowność, ostentacja, marnotrawstwo, nierzetelność. Parsons podkreśla fakt, że Marshall krytykuje bogacenie się dla samego bogacenia, potępia zjawisko nazwane później przez Thorsteina Veblena konsumpcją na pokaz. W Zasadach ekonomii angielski ekonomista stwierdza:

[...] byłoby korzystne, gdyby moralna presja społeczna mogła skłonić ludzi do zaniechania wszelkiego typu ostentacyjnego okazywania indywidualnego bogactwa. (Marshall, 1947/1920, s. 136, tłum. za Dzionek-Kozłowska, 2007, s. 300)

Znacznie dalej cel swojego działania gospodarczego wyznacza purytanin - jest nim zbawienie. Dla purytanina działania gospodarcze stanowią formę ascezy religijnej, praktykowanej w codziennym życiu. Weber określa ją mianem ascezy wewnątrz świata i traktuje jako przeciwieństwo ascezy odrzucającej świat. Cel działań gospodarczych podejmowanych przez purytanów ma sens religijny, ale również świeckie znaczenie. Na jednym końcu skali człowiek jest instrumentem bożej woli, na drugim zaś jako przedsiębiorca i robotnik staje się narzędziem produkcji dóbr ekonomicznych (Parsons, 1991e, s. 31).

Parsons przeciwstawia ujęcie Webera, który podkreśla znaczenie ascetyzmu w życiu gospodarczym, podejściu ortodoksyjnemu, sprowadzającemu wyjaśnienie aktywności gospodarczej jedynie do „,naturalnych”, instynktownych lub hedonistycznych tendencji ludzkiego zachowania. O ile ortodoksja ekonomiczna reduku- 
je potrzeby do maksymalizacji użyteczności, czyniąc z niej ostateczny cel działania, o tyle w analizie Webera Parsons dostrzega istotną zmianę: to określone wartości stają się potrzebami. Wartości religijne prowadzą purytanina do rozwijania cnót gospodarczych $(1991 \mathrm{~g}$, s. 71). W wymiarze „doczesnym” to one stają się celem działań gospodarczych, celem samym w sobie. Cnoty purytanina w życiu gospodarczym obejmują: pracowitość, dotrzymywanie zobowiązań, unikanie karczmy, hazardu, rozpusty, rzetelność, uczciwość w transakcjach handlowych, warunkującą zaufanie i kredyt w kontaktach gospodarczych (Kozyr-Kowalski, 1967, s. 232).

Między cnotliwością purytanina a szlachetnością dżentelmena istnieje spora zbieżność. Dla homo oeconomicus są one jednak niedostępne.

Co motywuje działania gospodarcze? Podejście utylitarno-hedonistyczne mocno uwypukla egoizm. Pomija natomiast inne elementy motywujące zachowania gospodarcze, które Parsons określa jako altruistyczne. Sporo zawiera ich teoria Marshalla. Parsons pieczołowicie przywołuje jego wypowiedzi, w których angielski ekonomista uznaje dążenie człowieka do zachowań zgodnych z własnym sumieniem i do uzyskania szacunku wśród innych za pierwszorzędną siłę ekonomiczną. Człowiek w coraz większym stopniu bierze pod uwagę przyszłość, ma więcej samokontroli, jest bardziej rozważny, a mniej samolubny (Parsons, 1968, s. 162-163).

Co więcej, egoistyczna motywacja działań gospodarczych często traci moc. Parsons ilustruje to na przykładzie Marshallowskiej analizy podaży pracy. U jej podstaw leży założenie, że wzrost wynagrodzenia wywołuje bezpośrednio wzrost wydajności pracy. Według Marshalla wzrost płacy wśród „bardziej niedouczonych i flegmatycznych ras i jednostek" skłoni je do mniejszej efektywności pracy, służy ona bowiem im jedynie do zaspokojenia potrzeb, do których przywykły. W ich przypadku pojawia się punkt zrównania przyjemności i przykrości wskazywany w koncepcjach hedonistycznych, który wyznacza granicę ich gospodarczego egoizmu. Z drugiej strony tych, których „umysłowy horyzont jest szerszy”, i którzy wykazują „twardość i elastyczność charakteru”, wzrost płacy skłania do dłuższej i cięższej pracy. Ich motywem nie jest egoizm prowadzący do zaspokojenia potrzeb, ale dążenie do podniesienia standardu życia, który wymaga wytworzenia nowych potrzeb przez nowe działania. Znamienna jest opinia Parsonsa, który głosi, że dla Marshalla przedsięwzięcie gospodarcze stwarza zasadniczą możliwość wykształcenia najszlachetniejszych cech ludzkiego charakteru. Bogactwo nabywane w tym procesie nie jest celem, ale raczej produktem ubocznym (Parsons, 1968, s. 142-143). Analogicznie motywację wykraczającą poza egoizm Parsons wyróżnia w Marshallowskiej analizie podaży kapitału i motywów oszczędzania. Wzrost stopy procentowej oferowanej za kapitał wywołuje wzrost rozmiarów oszczędzania. Zależności tej nie można jednak wyjaśnić, opierając się wyłącznie na założeniu, które Parsons określa jako hedonistyczne dążenia do zdobycia dóbr w przyszłości. W teorii Marshalla motywacja do oszczędzania jest bardzo złożona i wielką rolę odgrywa w niej wzgląd na innych, a zwłaszcza uczucia rodzinne. Reakcję na wzrost stopy procentowej thumaczy Parsons również racjonalnością podmiotów gospodarujących, której Marshall nigdy nie negował. 
Jedną z jej właściwości, która rozwija się wraz ze wzrostem standardu życia, jest antycypowanie przyszłości, liczenie się z coraz to nowymi potrzebami, które mogą zostać wytworzone przez przyszłe działania (Parsons, 1968, s. 146).

Marshallowski dżentelmen świata wolnego przemysłu i przedsiębiorczości wykracza poza motywację egoistyczną właściwą dla homo oeconomicus. Kieruje nim rycerskość gospodarcza. Zdaniem Joanny Dzionek-Kozłowskiej jest ona ukoronowaniem rozważań angielskiego ekonomisty na temat pożądanego kierunku rozwoju ludzkości (2007, s. 313). Symbolicznego wymiaru nabiera fakt, że Marshall przedstawił ją u kresu swojej kariery akademickiej.

Dla rycerza biznesu podstawowym motywem jest, ,pragnienie pokonania trudności, zdobycie uznania i przywództwa”. Czerpie on radość z czynienia rzeczy szlachetnych i trudnych, gardzi łatwymi zwycięstwami, cieszy się, gdy może pomóc tym, którzy tego potrzebują. Bogactwo jest dla niego znakiem sukcesu osiągniętego w działaniu, a nie celem samym w sobie. Odniesiony na polu gospodarczym sukces jest dowodem rzeczywistego przywództwa, jeśli, jak zauważa Marshall (1925), działalność nie jest oparta na oszustwie, wrogim niszczeniu rywali czy gnębieniu pracowników. $Z$ tego względu rycerskość gospodarcza wyklucza dwa typy zachowań. Pierwszy to zdobycie bogactwa za pomocą ,nieczystych" środków. Drugi ma w dużej mierze charakter rutynowy i polega na stałym przystosowywaniu się do okoliczności.

Moc rycerza biznesu opiera się przede wszystkim na własnej silnej woli. Przywódca gospodarczy potrafi stale zmieniać swoją wizję, kształtować ją tak, aby osiągnąć zamierzony cel. Jego wyobrażenia zagrażają zastanemu porządkowi, dlatego zazwyczaj nie uzyskuje on wsparcia ze strony innych. Warto w tym miejscu zauważyć, że pod tym względem analiza Marshalla znalazła kontynuację w teorii Josepha Schumpetera (1928; 1960).

Praca na własne ryzyko pozwala rycerzowi biznesu na pełną wolność w wykorzystywaniu własnej energii. Marshall zajmuje krytyczne stanowisko względem biurokracji. Dla człowieka interesu struktura biurokratyczna stanowi zagrożenie jego wolności. Wpływ biurokracji na ograniczenie wolności działań gospodarczych można obserwować w przedsięwzięciach zakładanych przez rząd, spółkach akcyjnych i trustach. Według Marshalla biurokracja nie może stać się alternatywą dla przywództwa i eksperymentów gospodarczych przeprowadzanych na własne ryzyko. Za głównego wroga rycerskości gospodarczej Marshall uznaje jednak kolektywizm (1925; 1932, s. 668-672). Jego wyznawcy domagają się przekazania państwu własności i zarządzania ziemią, maszynami i innymi czynnikami produkcji. Jednym z problemów, których nie można rozwiązać w ramach kolektywizmu, jest zapanowanie nad uczuciem zazdrości, stanowiącym ważną siłę motywującą zachowanie przeciętnego człowieka. Członkom kolektywu towarzyszy przekonanie, że inni otrzymują więcej niż oni za swój wkład ciężkiej i nieprzyjemnej pracy lub że inni otrzymują więcej niż wymaga tego komfort życia. Ich niezadowolenie nie znajduje ujścia na skutek ograniczenia wolności przemieszczania się w strukturze gospodarczej, do czego prowadzi kolektywizm. Rozważania Marshalla w dużej mierze dotyczą zjawiska, które współcześnie określa się mianem ,jazdy 
na gapę" i dla którego wciąż poszukuje się rozwiązania. Rycerskość gospodarcza wymiera w organizacjach kolektywistycznych.

Odmianą rycerskości gospodarczej jest rycerskość bogactwa. Motywuje ona ludzi bogatych do podejmowania działań, które wymagają wysokich zdolności i odpowiedzialności, lecz nie wiążą się z nimi wysokie dochody. Przepływ wielkich pieniędzy przez ich ręce nie budzi takich pokus, jak w przypadku ludzi ubogich. Według Marshalla pozostawienie bogactwa wyłącznie krewnym jest czynem niehonorowym. Dziedziczenie niszczy bowiem ich charakter, pozwalając na to, aby od dzieciństwa spełniali każdą swoją zachciankę. Człowiek bogaty może łagodzić cierpienia tych, którzy nie ze swojej winy nie dają sobie rady (Marshall, 1925, s. 323-346).

Rycerskość gospodarczą dżentelmena można traktować jako dążenie do zachowania w warunkach społeczeństwa kapitalistycznego chociaż części etosu rycerskiego. Według Dzionek-Kozłowskiej (2007, s. 315) normatywny wzorzec osobowy stworzony przez Marshalla stanowi krok w kierunku uwypuklenia i rozwinięcia wzorca moralnego powszechnie aprobowanego w jego epoce i kraju (cf. Dzionek-Kozłowska \& Matera, 2015, s. 43-45).

Dla purytanów siłę pozytywnie motywującą działania gospodarcze stanowi boże powołanie. Przełamuje ono negatywną motywację do pracy. Nie jest ona traktowana jako klątwa Adama, kara za grzech pierworodny. Ponadto przestaje być postrzegana jedynie jako technika służąca do walki z pokusami ciała. Praca zgodna z powołaniem stanowi pierwszy obowiązek człowieka posłusznego bożej woli.

Motywująca moc powołania polega również na tym, że skłania ono do przekroczenia granicy, której nie pokonałby człowiek kierujący się czystym hedonizmem. W jego działaniach pojawia się punkt krytyczny, gdzie dalszy wysiłek i związana z nim przykrość zrównują się z kolejnym przyrostem satysfakcji, prowadząc do zaprzestania dalszej pracy i zadowolenia się już osiągniętymi wynikami. Purytanin czuje się natomiast zobowiązany do ciągłego kontrolowania stanu łaski, co utwierdza go w przekonaniu, że jest człowiekiem predestynowanym przez Boga do zbawienia. Powodzenie w ziemskim powołaniu powiększa stan jego pewności, że jest bożym wybrańcem. Dla prawdziwego wyznawcy praca przestaje stanowić przykrą konieczność, której musi się podporządkować, oznacza natomiast najlepszy sposób realizacji jego religijnych interesów. Powołanie purytanina pozwala przezwyciężyć próżniactwo i niedostatek umiejętności zawodowych, których żadną miarą nie można usprawiedliwić. Purytanizm nie pozostawia miejsca dla żebractwa i jałmużny. Zgodnie z doktryną predestynacji brak powodzenia w działaniach gospodarczych jest traktowany jako wyraz bożego potępienia (Parsons, 1968, s. 527-528).

Parsons w utylitarno-hedonistycznym nastawieniu homo oeconomicus dostrzega nie tyle siłę motywującą do działań gospodarczych, co skłaniającą do ograniczenia ich zakresu. Sprzyja ono utrzymaniu postawy, którą Weber określa mianem tradycjonalizmu. Według Parsonsa redukuje ona dążenie do zysku do poziomu nasycenia potrzeb, orientuje działalność zarobkową na zapewnienie stałego standardu życia. Tradycyjną postawą nie jest dążenie do cięższej pracy, gdy istnieje możliwość zwiększenia wynagrodzenia, lecz zmniejszenie wysiłku, 
by zarobić dotychczas uzyskiwaną kwotę. Reinhard Bendix, autor wpływowej pracy Max Weber. Portret uczonego (1975), ten aspekt tradycjonalizmu ekonomicznego wyraża zasadą: „sam żyj i daj żyć innym”. Może on cechować zachowanie robotnika, gdy woli on mniej pracować niż więcej zarabiać, gdy w godzinach pracy szuka maksymalnej wygody lub minimum wysiłku, gdy nie umie lub nie chce przystosować się do nowych metod pracy. Według Bendiksa stanowi on właściwość działań przedsiębiorcy wtedy, gdy produkuje on zróżnicowane, a nie standardowe artykuły, przeznacza na pracę umiarkowaną część dnia, pracuje powoli, wystarczają mu zarobki umożliwiające wygodne życie, gdy wreszcie jego stosunki z pracownikami, klientami i konkurentami mają bezpośredni i osobisty charakter (1975, s. 52).

Według Parsonsa przełamywanie tradycjonalizmu ma jeszcze jeden aspekt. Polega on na zerwaniu z pokoleniowym przekazywaniem sposobów gospodarowania. Liczy się jedynie cel ostateczny, maksymalizacja zarobku, zaś poszczególne środki są wybierane w zależności od wymagań danej sytuacji (1968, s. 513-515).

Na czym polega racjonalność działań gospodarczych? Parsons sprowadza ją do kwestii zarządzania (command over) środkami zaspokojenia potrzeb (1968, s. 162). W podejściu utylitarno-hedonistycznym postulat racjonalności stanowi podstawowe założenie $\mathrm{w}$ badaniu procesu nabywania pożądanych dóbr i świadczeń. Ale według Parsonsa ogranicza się go do zasady zaspokojenia potrzeb najmniejszym możliwym wysiłkiem. Racjonalność działań zostaje utożsamiona z egoizmem jednostki. Charakter ostatecznych celów, dla których środki te mają zostać użyte, jest całkowicie obojętny. A przecież, o ile normy zachowania gospodarczego mogą pozostawać takie same, płynące z niego dochody mogą służyć zarówno zaspokojeniu zachcianek, jak i pomocy dla biednych.

W teorii Marshalla Parsons dostrzega próbę wyjścia poza utylitarno-hedonistyczny sposób pojmowania racjonalności działań gospodarczych. Dla dżentelmena świata wolnego przemysłu i przedsiębiorczości racjonalność staje się etycznym zobowiązaniem. Wyłaniają się sposoby gospodarowania nieosiągalne dla homo oeconomicus. Racjonalność prowadzi do starannej, systematycznej administracji zasobami i zdolnościami, liczenia się z wymaganiami, jakie mogą pojawić się w przyszłości, ostrożnej regulacji konsumpcji i zwyczajów życiowych w celu dostosowania ich do wydajności produkcyjnej. Ta ostatnia jest produktem ubocznym, a nie przyczyną wyłonienia się racjonalności w działaniach gospodarczych. Według Parsonsa Marshall nie tylko oddziela egoizm od racjonalności. Wraz ze wzrostem tej ostatniej człowiek staje się mniej egoistyczny (Parsons, 1968, s. 161-164).

Znacznie radykalniej racjonalność gospodarczą przekształca purytanin. Według Parsonsa $\mathrm{z}$ hedonistycznego punktu widzenia jego racjonalność ekonomiczna jest niezrozumiała. Irracjonalny jest ascetyzm kierujący jego działaniami gospodarczymi. Ale to właśnie tendencja ascetyczna powoduje, że racjonalność purytanina w działaniach gospodarczych przynosi efekt niedostępny dla homo oeconomicus. Dąży on do zysku, lecz nie po to, aby czerpać przyjemność z jego wydawania. Jeśli ograniczenie konsumpcji połączyć z dążeniem do zarobku, to nieuchronny praktyczny rezultat jest oczywisty: jest nim tworzenie kapitału wskutek ascetycznego przymusu oszczędzania. Pomnażanie majątku przy jednocze- 
snym powstrzymywaniu się od korzystania $\mathrm{z}$ niego jest nie do pogodzenia $\mathrm{z}$ racjonalnością, którą kieruje się homo oeconomicus (Parsons, 1968, s. 528). Z utylitarno-hedonistycznego punktu widzenia równie irracjonalny jest stosunek purytanina do pracy. Wyklucza on możliwość przedwczesnej rezygnacji z niej. Człowiek, który nie ,produkuje”, pomimo że pozwalają mu na to siły i stan zdrowia, zaniedbuje swój etyczny obowiązek. „Irracjonalność” purytanina wnosi w życie gospodarcze korzyść nie do zdobycia dla homo oeconomicus. Osiąga się ją poprzez eliminację lub co najmniej ograniczenie postaw rentierskich.

$\mathrm{W}$ jeszcze jednym aspekcie racjonalność gospodarcza purytanina wykracza poza zasadę zaspokojenia potrzeb najmniejszym możliwym wysiłkiem. Poddaje on swoje działania zarobkowe surowej dyscyplinie i kontroli, przełamując impulsywne dążenie do zysku, charakterystyczne dla kapitalizmu awanturniczego (Parsons, 1968, s. 515).

Wiele dzieli purytańską ascezę od świata wolnego przemysłu i przedsiębiorczości. Purytanina i dżentelmena łączy natomiast antyrentierskie nastawienie. Stanowi ono cechę wyróżniającą racjonalność ich działań gospodarczych w stosunku do racjonalności homo oeconomicus.

\section{Biurokracja bez, ,biurokracji”}

Jak zachować bezinteresowność w działaniach gospodarczych, w „odczarowanym" świecie, gdzie korzenie religijne obumarły, a masowość wyrugowała rycerskość? Dla Parsonsa rozwiązaniem jest biurokracja.

Punktem wyjścia jego analizy jest Weberowska teoria biurokracji. Ale Parsons znacznie poza nią wykracza. W jego ujęciu koncepcja biurokracji stanowi narzędzie analizy rozwoju kapitalizmu. Uznaje Weberowskiego ducha kapitalizmu za szczególny przypadek ducha zawodowego, który jest niezbędny do efektywnego funkcjonowania biurokracji. Racjonalno-burżuazyjny kapitalizm, który Weber przeciwstawia kapitalizmowi awanturniczemu, jest jego zdaniem formą organizacji biurokratycznej (Parsons, 1968, s. 505, 515). Według amerykańskiego socjologa elementy, które odróżniają kapitalizm od socjalizmu, takie jak: konkurencja, własność prywatna, antagonizm klasowy między burżuazją a proletariatem, mimo że są one częścią teorii Webera, mają znaczenie drugorzędne w porównaniu z rolą biurokracji. Kapitalizm jest przede wszystkim organizacją biurokratyczną służącą zdobyciu zysku pieniężnego (Parsons, 1991e, s. 26).

Dla Parsonsa ważną cechą Weberowskiego typu biurokracji jest jej bezosobowy (impersonal) charakter. Bezosobowe - z punktu widzenia członków - są jej cele. Bezosobowe jest jej funkcjonowanie. Rola każdego członka biurokracji jest traktowana jako „urząd”, sprawowany w oparciu o przypisaną do niego określoną władzę, której zakres jest wyłączony spod osobistego wpływu członków biurokracji. Bezosobowość organizacji biurokratycznej odnosi się do technicznych kryteriów, które decydują o wyodrębnieniu funkcji, hierarchicznego podporządkowania władzy organowi centralnemu, wyspecjalizowanych kwalifikacji wymaganych od jej człon- 
ków. Ponadto bezosobowość to cecha przypisywana przez Parsonsa wynagrodzeniu otrzymywanemu w strukturze biurokratycznej. Pensja jest przede wszystkim gwarancją poziomu życia właściwego dla danej rangi urzędowej, w mniejszym zaś stopniu nagrodą czy ekwiwalentem za poświęcenie (1968, s. 506).

W organizacji biurokratycznej bezinteresowność, w odróżnieniu od szlachetności dżentelmena czy cnotliwości purytanina, nabiera bezosobowego charakteru. Zostaje ona wpisana w system ról i oczekiwań kierowanych w stosunku do ludzi zajmujących stanowiska $\mathrm{w}$ jej strukturze. Parsons sprowadza bezinteresowność roli do jej orientacji na zbiorowość. Obliguje ona wówczas podmiot do realizacji wspólnych interesów zbiorowości. Są one nadrzędne w stosunku do interesów prywatnych jednostki, których dominacja jest z kolei charakterystyczna dla orientacji roli na własną osobę. Na przykład prywatnym interesem urzędnika publicznego jest powodzenie finansowe, które może brać pod uwagę przy wyborze miejsca zatrudnienia, ale oczekuje się od niego, że nie będzie się nim kierował, wydając decyzje zgodnie z wymaganiami polityki publicznej nawet wtedy, gdy są one sprzeczne z jego prywatnym interesem (2009, s. 51).

Na zbiorowość zorientowane są wolne zawody. Interes własny jednostki polega na dostosowaniu się do kodeksu instytucjonalnego obowiązującego w jej środowisku zawodowym. Jak zauważa Parsons, istotą wzoru instytucjonalnego wolnych zawodów jest ograniczenie agresywnej pogoni za własną korzyścią (1972, s. 48-73). Na przykład łamanie kodeksu zawodowego przez lekarza, nawet jeśli pozwoliłoby mu to na osiąganie bezpośrednich korzyści finansowych, nie leży w jego interesie. Tam, gdzie struktura instytucjonalna jest mocno zakorzeniona, postępowanie to wywołałoby ze strony jego kolegów po fachu czy pacjentów reakcję, która mogłaby zaszkodzić jego pozycji zawodowej. Orientację wolnych zawodów na zbiorowość chroni szereg ukrytych mechanizmów kontrolnych, na przykład zwyczajowe polecanie sobie pacjentów przez lekarzy prowadzących prywatną praktykę.

Nadrzędność własnej korzyści nad interesem zbiorowości wpisana jest natomiast w definicję instytucjonalną roli „dobrego” człowieka interesu. Szacowanie możliwości płatniczych klientów, konkurencja cenowa, szeroki zakres reklamy są akceptowane i dozwolone. Zyski pieniężne są bezpośrednim miernikiem powodzenia w działalności gospodarczej.

Parsons podkreśla jednak, że organizowanie w świecie biznesu korporacji o wielkiej skali działania modyfikuje sytuację. Zdobycie zysku jest celem firmy jako całości, dla jednostki liczy się przede wszystkim jej stanowisko i pensja. W strukturze biurokratycznej orientacja na zbiorowość zyskuje prymat nad orientacją na własną osobę. Według Parsonsa rozwój korporacji niweluje pod tym względem różnicę między światem biznesu a wolnymi zawodami. Stanowisko menedżerskie w firmie w dużym stopniu ma charakter powierniczy (fiduciary). W obu przypadkach wzór instytucjonalny roli zawodowej nakłada na jednostkę określone obowiązki i odpowiedzialność. Na ogół postępowanie zgodne z nimi leży w jej własnym interesie (1972, s. 67-68).

Parsons w eseju Motywacja działalności gospodarczej (1972) wyróżnia szereg elementów, które motywują jednostkę do zorientowania roli zawodowej na 
zbiorowość. Stanowią one bezinteresowne elementy motywacji. Określa je ogólnym pojęciem satysfakcji. Pierwszym jej składnikiem jest ,szacunek do samego siebie" (self-respect). Jeśli normy moralne są wbudowane w strukturę osobowości, zadowolenie jednostki zależy od stopnia, w jakim się ona do tych norm stosuje. Uzupełnieniem tego składnika bezinteresownej motywacji jest „uznanie” (recognition). Oznacza ono moralny szacunek osób, których opinię się ceni. Aprobata, podziw, a nawet zazdrość schlebiają jednostce i dają jej zadowolenie. Utrata szacunku tych, od których się go oczekiwało, jest jednym z najcięższych ciosów, jakie można zadać satysfakcji jednostki. Trzeci składnik jest najbardziej zbliżony do podejścia właściwego dla analizy ekonomicznej. Można go określić jako „drugą stronę" motywacji opartej na własnej korzyści. Na przykład dochody pieniężne mają znaczenie symboliczne w porównaniu z takimi wartościami, jak aprobata czy szacunek. Według Parsonsa stanowią one potrzeby istniejące niezależnie od działań, poprzez które środki do ich zaspokojenia są osiągane. Czwarty składnik to „przyjemność” (pleasure). Odegrał on ważną rolę w historii myśli ekonomicznej. Przyjemność może być jednym z podstawowych celów, środkiem do osiągnięcia których jest działanie gospodarcze. Ale, jak zauważa Parsons, można jej doświadczać, po prostu wykonując czynności związane z rolami o znaczeniu gospodarczym, odczuwając ją w pracy. Może ona towarzyszyć działalności gospodarczej. Piąty składnik to postawa emocjonalna wobec innych ludzi określona mianem „uczucia” (affection). Wywołuje ono „odzew” (response) z ich strony. Jako element bezinteresowny ma on ogromne znaczenie dla sytuacji zawodowej i motywacji jednostek. Według Parsonsa ważnym motywem wykonywania „dobrej roboty" może być przyjaźń łącząca daną jednostkę ze współpracownikami (1972, s. 59-62).

Bezinteresowność biurokracji sprowadza się nie tylko do technicznego aspektu jej funkcjonowania, który Parsons określa jako jej bezosobowość. Jest ona również właściwością ról pełnionych w jej obrębie, wyrazem ich zorientowania na zbiorowość.

Parsons przeciwstawia racjonalność biurokracji tradycjonalizmowi i działaniom instynktownym. Cechują ją dalekosiężne zastosowanie nauki w produkcji i organizacji, długofalowe planowanie operacji, nastawienie na przyszłość. W organizacji biurokratycznej jednostki ostrożnie i systematycznie planują swoje życie, eliminując wszelkie działania sprzeczne z przyjętym planem (1991g, s. 70).

Pojęcie biurokracji funkcjonuje również w zgoła odmiennym niż w przyjętym przez Parsonsa znaczeniu. Jest ono wówczas synonimem niesprawności organizacji, jej marnotrawstwa, arogancji osób zajmujących stanowiska.

Wszystkich oznak degeneracji pozbawiona jest koncepcja Parsonsa, którą z tego względu można określić mianem biurokracji bez „biurokracji”. Zasługuje ona na pozytywną krytykę. „Młodemu” Parsonsowi można postawić zarzut nazbyt idealistycznego czy wręcz idyllicznego podejścia do zjawiska biurokracji. Twórczość Maksa Webera, wielkiego poprzednika i źródła inspiracji dla amerykańskiego socjologa, dostarcza środków obrony stworzonej przez niego koncepcji. Ujęcie Parsonsa można bowiem traktować jako typ idealny, prawidło, do którego w większym lub mniejszym stopniu zbliżają się funkcjonujące organizacje biuro- 
kratyczne. Wyróżnione przez amerykańskiego socjologa bezinteresowne elementy motywacji członków biurokracji pozwalają na ich porównanie pod względem zorientowania na zbiorowość za pomocą kategorii szacunku społecznego, poświęcenia zawodowego, integracji grupowej.

Koncepcja „młodego” Parsonsa kryje jednak pułapkę. Opisuje on formalne warunki satysfakcji zawodowej członków organizacji biurokratycznych, ale biurokracje mogą służyć różnym celom i realizować różne wartości. Poświęcenie zawodowe i szacunek społeczny to właściwości, które mogą przysługiwać technostrukturze przedsiębiorstw, rozwijającej gospodarkę i dobrostan społeczeństwa, jak i członkom organizacji biurokratycznych utrzymujących ustroje totalitarne.

Twórczość dojrzałego Parsonsa dostarcza narzędzi teoretycznych służących przezwyciężeniu słabości koncepcji bezinteresowności i biurokracji. Po pierwsze należy tutaj wskazać na typologię wzorów wartości w kulturach społeczeństw, szczególnie na pary uniwersalizm-partykularyzm oraz osiąganie-przypisanie. Organizacje biurokratyczne funkcjonujące w społeczeństwie uniwersalistycznoosiągnięciowym mają większą szansę uniknięcia różnego typu partykularności i przypisania niż w przypadku innych układów wartości. Po drugie teoria systemu społecznego Parsonsa umożliwia bardziej pogłębioną analizę możliwości przekraczania granic korzyści własnych przez jednostki, w tym członków biurokracji, niż „młodzieńcza” koncepcja bezinteresowności. System społeczny opiera się bowiem na czterech imperatywach funkcjonalnych (AGIL), które są równorzędne i niezbędne dla jego prawidłowego działania ${ }^{1}$. Liczy się zarówno funkcja osiągania celów i adaptacyjna, jak i, co ważne w kontekście bezinteresowności, funkcje integracyjne oraz kultywowania wzorów i usuwania napięć. Oprócz tego koncepcja równowagi Parsonsa może stanowić narzędzie analizy realnie istniejących organizacji biurokratycznych. Szczególne znaczenie w twórczości amerykańskiego socjologa, której przedmiotem są zjawiska gospodarcze, posiada jego dzieło napisane wspólne z Neilem J. Smelserem pod znamiennym tytułem Economy and Society. A Study in the Integration of Economic and Social Theory (1957). Zawiera ono między innymi istotną w kontekście rozważań o biurokracji koncepcję stosunków kontraktowych w gospodarce: kontraktów inwestycyjnych i umów o pracę. Parsons analizuje je przy użyciu teorii systemu społecznego, uwzględniając ich odrębne wymiary zgodnie z modelem AGIL, jak również ukazując różne możliwe stany (równowagę, inflację i deflację) w wymianie między stronami kontraktów. W pracy Strategie dochodowe różnych kategorii podmiotów na rynku

\footnotetext{
1 Teoria systemu społecznego Parsonsa opiera się na założeniu równowagi między podsystemami, utrzymywanej poprzez wymianę odpowiednich typów wkładów i wytworów. Według Jacka Tittenbruna źródeł tej teorii można doszukiwać się w koncepcji input-output analysis amerykańskiego ekonomisty rosyjskiego pochodzenia Wassily’ego Leontiefa, która z kolei genetycznie wywodzi się z tablic obrotu kapitału między działami gospodarki, skonstruowanymi przez Karola Marksa w Kapitale, dla której to idei jeszcze dalej idącej inspiracji można poszukiwać w tablicach ekonomicznych cenionego przez Marksa czołowego ekonomisty szkoły fizjokratycznej, François Quesnaya (Tittenbrun, 2011, s. 165). Należy również zauważyć, że Parsons posługuje się pojęciem niestabilnej czy też ruchomej równowagi, stosując pojęcia inflacji i deflacji w wymianie wkładów i wytworów przebiegającej w systemie społecznym, dzięki czemu jego ujęcie teoretyczne zyskuje na realizmie. Teoria systemu społecznego umożliwia analizę w wymiarze makro, tj. społeczeństwa jako całości, mezo - np. przedsiębiorstwa czy mikro - np. gospodarstwa domowego.
} 
kapitalistycznym podejmuję opartą na teorii Parsonsa analizę relacji kontraktowych między zarządcami przedsiębiorstw a akcjonariuszami, pracownikami i konsumentami (Wechta, 2016).

\section{Wnioski}

Przeprowadzona przez Parsonsa krytyka postawy homo oeconomicus nie jest wyrazem nierzadkiej w środowiskach intelektualnych wrogości wobec kapitalizmu. Amerykański socjolog ukazuje ograniczenia, jakie niesie ona dla rozwoju gospodarczego. A jest ich całkiem sporo. Homo oeconomicus nie rozwinie cnót gospodarczych, które skłoniłyby go do poszukiwania nowych celów i wyzwań. Jego działania prowadzą gospodarkę do stanu, który Schumpeter (1960) określa mianem ruchu okrężnego. Egoistyczna motywacja ogranicza zakres jego aktywności. Działania gospodarcze prowadzi on w sposób tradycyjny. Sednem jego racjonalności jest zdobycie pozycji zwalniającej z konieczności wykonywania pracy. Homo oeconomicus chce być rentierem.

Bezinteresowność jako zdolność do przekraczania granic własnej korzyści nie zastępuje klasycznych czynników produkcji, ale może wydatnie wspomóc rozwój gospodarczy. Bezinteresowność ekonomiczna może przejawiać się w działaniach Marshallowskiego dżentelmena czy opisywanego przez Webera purytanina. Dla nich dążenie do zysku jest środkiem, a nie celem. Obie postawy mają jednak charakter elitarny. Nawet jeśli pominąć ich historyczne uwarunkowanie, to ich przyjęcie wymaga przymiotów indywidualnych. Nie są one dostępne dla wszystkich.

Znacznie bardziej egalitarny charakter ma biurokracja. Bezinteresowność zostaje wpisana w role pełnione w jej strukturze. Nabierają one przez to bezosobowego charakteru. Talcott Parsons w swojej analizie przekracza granice pojmowania biurokracji wyznaczone przez Maksa Webera. Amerykański socjolog odrzuca pesymizm niemieckiego uczonego $\mathrm{w}$ stosunku do biurokratycznej organizacji kapitalizmu, zdaniem którego nie pozostawia ona miejsca dla twórczych elementów w ludzkich działaniach.

Analiza zjawiska biurokracji to główny punkt ataku Parsonsa na ortodoksję ekonomiczną, która - jak twierdzi - z wytłumaczeniem zjawiska biurokracji po prostu sobie nie radzi (1991e, s. 37). Nie dysponuje ona odpowiednimi narzędziami. Jeśli celem biurokracji miałoby być indywidualne dążenie do własnej korzyści, to praktycznie nie mogłaby ona funkcjonować. Sprowadzenie motywacji jej członków jedynie do egoizmu prowadziłoby do rytualizmu w wykonywaniu powierzonych im ról, a zasada najmniejszego wysiłku do ,jazdy na gapę", dążenia do korzystania przez członków organizacji z dóbr bez ponoszenia kosztów ich wytwarzania. Ortodoksyjna teoria ekonomiczna, posługując się modelem racjonalnego, egoistycznego zachowania jednostki, bardziej nadaje się do badania patologii struktur organizacyjnych niż samej biurokracji. 


\section{Bibliografia}

Bendix, R. (1975). Max Weber. Portret uczonego. Warszawa: Państwowe Wydawnictwo Naukowe.

Blaug, M. (1995). Metodologia ekonomii. Warszawa: Wydawnictwo Naukowe PWN.

Camic, Ch. (1991). Introduction: Talcott Parsons before The Structure of Social Action. In Ch. Camic (Ed.), Talcott Parsons. The early essays (s. IX-LXIX). University of Chicago Press.

Dzionek-Kozłowska, J. (2007). System ekonomiczno-społeczny Alfreda Marshalla. Warszawa: Wydawnictwo Naukowe PWN.

Dzionek-Kozłowska, J. (2018). Model homo oeconomicus. Geneza, ewolucja, wplyw na rzeczywistość gospodarczą. Lódź: Wydawnictwo Uniwersytetu Łódzkiego.

Dzionek-Kozłowska, J., \& Matera, R. (2015). Ethics in economic thought. Selected issues and various perspectives. Lodz, Krakow: Lodz University Press, Jagiellonian University Press.

Kozyr-Kowalski, S. (1967). Max Weber a Karol Marks. Socjologia Maxa Webera jako „,pozytywna krytyka materializmu historycznego”. Warszawa: Książka i Wiedza.

Kozyr-Kowalski, S. (1990). Pareto jako krytyk Marksa i ideologicznego pojmowania społeczeństwa. Ruch Prawniczy, Ekonomiczny i Socjologiczny, 3-4, 197-213.

Marshall, A. (1925). Social possibilities of economic chivalry. In A. C. Pigou (Ed.), Memorials of Alfred Marshall (s. 323-346). London: Macmillan.

Marshall, A. (1932). Industry and trade. London: Macmillan.

Marshall, A. (1947/1920). Principles of economics. London: Macmillan.

Parsons, T., \& Smelser, J. N. (1957). Economy and society. A study in the integration of economic and social theory. London: Routledge \& Kegan Paul.

Parsons, T. (1968). The structure of social action. A study in social theory with special reference to a group of recent European writers. New York: Free Press.

Parsons, T. (1972). Szkice z teorii socjologicznej. Warszawa: Państwowe Wydawnictwo Naukowe.

Parsons, T. (1991a). Sociological elements in economic thought. In Ch. Camic (Ed.), Talcott Parsons. The early essays (s. 181-230). University of Chicago Press.

Parsons, T. (1991b). Some reflection on „The Nature and Significance of Economics”. In Ch. Camic (Ed.), Talcott Parsons. The early essays (s. 153-180). University of Chicago Press. 
Parsons, T. (1991c). Service. In Ch. Camic (Ed.), Talcott Parsons. The early essays (s. 47-50). University of Chicago Press.

Parsons, T. (1991d). On certain sociological elements in Professor Taussig's Thought. In Ch. Camic (Ed.), Talcott Parsons. The early essays (s. 259278). University of Chicago Press.

Parsons, T. (1991e). „Capitalism” in recent German literature: Sombart and Weber. In Ch. Camic (Ed.), Talcott Parsons. The early essays (s. 3-38). University of Chicago Press.

Parsons, T. (1991f). H. M. Robertson on Max Weber and his school. In Ch. Camic (Ed.), Talcott Parsons. The early essays (s. 57-68). University of Chicago Press.

Parsons, T. (1991g). Economics and sociology: Marshall in relation to the thought of his time. In Ch. Camic (Ed.), Talcott Parsons. The early essays (s. 69-94). University of Chicago Press.

Parsons, T. (2009). System społeczny. Kraków: Zakład Wydawniczy „Nomos”.

Schumpeter, J. A. (1928). The instability of capitalism. Economic Journal, 38(151), 361-386.

Schumpeter, J. A. (1960). Teoria rozwoju gospodarczego. Warszawa: Państwowe Wydawnictwo Naukowe.

Tittenbrun, J. (2011). Economy and society: Economic sociology revisited. Cambridge Scholars Publishing.

Weber, M. (1995). Osobliwości kultury zachodniej. W: M. Weber, Szkice z socjologii religii. Warszawa: Książka i Wiedza.

Wechta, P. (2016). Strategie dochodowe różnych kategorii podmiotów na rynku kapitalistycznym. Poznań: Wydawnictwo Naukowe UAM. 